\title{
Dynamic Simulation of an Absorption Cooling System with Different Working Mixtures
}

\author{
Jesús Cerezo $^{1, *(1)}$, Rosenberg J. Romero ${ }^{1}$ (D) ${ }^{\text {, Jonathan Ibarra }}{ }^{1}$ (D), Antonio Rodríguez ${ }^{1}$, \\ Gisela Montero $^{2}$ (D) and Alexis Acuña 2 (D) \\ 1 Centro de Investigación en Ingeniería y Ciencias Aplicadas, Universidad Autónoma del Estado de Morelos, \\ Av. Universidad 1001, Cuernavaca 62209, Morelos, Mexico; rosenberg@uaem.mx (R.J.R.); \\ jibarra@uaem.mx (J.I.); antonio_rodriguez@uaem.mx (A.R.) \\ 2 Universidad Autónoma de Baja California, Blvd. Benito Juárez y Calle de la Normal S/N, Insurgentes Este, \\ Mexicali 21280, Baja California, Mexico; gmontero@uabc.edu.mx (G.M.); alexis.acuna@uabc.edu.mx (A.A.) \\ * Correspondence: jesus.cerezo@uaem.mx; Tel.: +52-777-329-7000
}

Received: 18 December 2017; Accepted: 19 January 2018; Published: 23 January 2018

\begin{abstract}
High consumption of electricity represents an economic and social problem in warm places, caused by the massive use of cooling machines. Absorption systems are a sustainable method for air conditioning applications. However, environmental conditions should be analyzed to avoid crystallization problems of the working mixture. This article presents a thermal analysis of a solar absorption cooling system in dynamic conditions using $\mathrm{NH}_{3}-\mathrm{H}_{2} \mathrm{O}, \mathrm{H}_{2} \mathrm{O}-\mathrm{LiBr}, \mathrm{NH}_{3}-\mathrm{NaSCN}$, $\mathrm{NH}_{3}-\mathrm{LiNO}_{3}$, and $\mathrm{H}_{2} \mathrm{O}-\mathrm{LiCl}$ working mixtures using Equation Engineering Solver (EES) and TRaNsient SYstem Simulation (TRNSYS) software. A solar collector area of $42.5 \mathrm{~m}^{2}$ was selected to carry out the thermal analysis. The results showed that $\mathrm{H}_{2} \mathrm{O}-\mathrm{LiCl}$ obtained the maximum solar $(0.67)$ and minimum heating (0.33) fraction. However, it obtained the maximum lost heat fraction (0.12), in spite of obtaining the best coefficient of performance (COP) among the other working mixtures, due mainly to a crystallization problem. The gain fraction (GF) parameter was used to select the adequate solar collector number for each working mixture. $\mathrm{NH}_{3}-\mathrm{LiNO}_{3}$ and $\mathrm{NH}_{3}-\mathrm{H}_{2} \mathrm{O}$ obtained the highest GF (up 6), and both obtained the maximum solar (0.91) and minimum heating (0.09) fraction, respectively, using 88.8 and $100.4 \mathrm{~m}^{2}$ of solar collector area, respectively.
\end{abstract}

Keywords: solar absorption cooling; evacuated tube solar collector; dynamic condition; crystallization

\section{Introduction}

Cities located in warm places have a high consumption of electricity, especially in the summertime. This is a socio-economic and environmental problem that is due to the use of air conditioning and refrigeration. They are largely based on the consumption of non-renewable primary resources.

Solar-powered absorption cooling systems use solar heat to drive an absorption chiller and produce a cooling effect in a sustainable way; however, some working mixtures have crystallization problems depending on the changes in environmental temperature, and this is the main problem for these devices because it blocks the internal pipes and stops the chiller operation [1].

In the literature, there are some studies about absorption cooling systems (ACS) in dynamic conditions: Ahmed et al. [2] carried out a simulation based on a performance analysis of a solar assisted single effect absorption cooling system for two system configurations in TRaNsient SYstem Simulation (TRNSYS). In configuration 1 (C-1), the working fluid returning from the generator of the absorption chiller flows toward the hot storage tank. In configuration 2 (C-2), the working fluid returning from the absorption chiller may become isolated from the collector-storage tank loop if the fluid temperature in the storage tank is inferior to the required temperature and is directly fed to the 
auxiliary boiler. The results showed that C-2 resulted in higher energy saving than C-1 for the whole summer season.

Stanciu et al. [3] analyzed an $\mathrm{NH}_{3}-\mathrm{H}_{2} \mathrm{O}$ absorption cooling system driven by solar energy. A fully mixed hot water storage tank was used to provide the thermal energy to the generator from the heat collected by a fixed oriented parabolic trough collector. According to the author's results, for the longest continuous operation of the $\mathrm{NH}_{3}-\mathrm{H}_{2} \mathrm{O}$ cooling system (from 09:00 to 17:10) $10 \mathrm{~m} \times 2.9 \mathrm{~m}$ parabolic trough collector (PTC) aperture dimensions with a $0.16 \mathrm{~m}^{3}$ storage tank volume were calculated at $10^{\circ} \mathrm{C}$ of evaporator temperature. In the same year, Stanciu et al. [4] simulated a solar driven cooling system consisting of a single effect $\mathrm{H}_{2} \mathrm{O}-\mathrm{LiBr}$ absorption cooling system, a parabolic trough collector, and a storage tank module was analyzed for one full operation day. The simulation was constrained to operate at the maximum exergetic efficiency of the absorption system, under a time-dependent cooling load. A constant evaporator of $10{ }^{\circ} \mathrm{C}$ was considered. To set up the solar assembly, two commercial PTCs were selected, namely PT1-IST and PTC 1800 Solitem. The results showed that the best choice for the studied case was the use of two commercial PTC 1800 collectors connected in series with a modular storage tank with capacities of 90 and $140 \mathrm{~kg}$. The simulation incorporated the fact that the system operates continuously between 09:00 to 18:00 on a calm day $(0.2 \mathrm{~m} / \mathrm{s}$ wind velocity). On a windy day (considering a wind speed of $5 \mathrm{~m} / \mathrm{s}$ ), the computations revealed that the operation time interval was reduced to 09:00 to 17:40 due to important energy losses in the PTC.

Sokhansefat et al. [5] carried out a parametric analysis to find the optimum configuration for a 5 -ton capacity solar absorption system in transient conditions using TRNSYS software in Tehran. The results indicated that the performance of the setup is capable of $28 \%$ enhancement. The optimum values were a collector area of $55 \mathrm{~m}^{2}$, storage tank volume of $1 \mathrm{~m}^{2}$, temperature set point of the auxiliary boiler of $77^{\circ} \mathrm{C}$, solar collector mass flow rate at $1000 \mathrm{~kg} / \mathrm{h}$, and collector slope of $33^{\circ}$.

Antonopoulos and Rogdakis [6] studied the performance of absorption heat pumps using $\mathrm{NH}_{3}-\mathrm{LiNO}_{3}$ and $\mathrm{NH}_{3}-\mathrm{NaSCN}$ in Atenas, Greece. The results showed that $\mathrm{NH}_{3}-\mathrm{LiNO}_{3}$ was better than $\mathrm{NH}_{3}-\mathrm{NaSCN}$ for heating because it provides a higher heat-gain factor and useful thermal power. For cooling the $\mathrm{NH}_{3}-\mathrm{LiNO}_{3}$ system provides a higher cooling power, while $\mathrm{NH}_{3}-\mathrm{NaSCN}$ achieves a higher coefficient of performance (COP).

Florides et al. [7] presented an $\mathrm{H}_{2} \mathrm{O}-\mathrm{LiBr}$ solar absorption cooling system simulation in TRNSYS software under typical conditions in Nicosia, Cyprus. That study consisted of optimizing the storage tank size, slope, and area of the parabolic solar collector. The results showed that the ideal size of the solar collector was $15 \mathrm{~m}^{2}$ with an inclination of $30^{\circ}$ and $600 \mathrm{~L}$ of the storage tank for the generation of $84,240 \mathrm{MJ}$. Arzoz et al. [8] presented a simulation of a double effect absorption cooling of $3 \mathrm{~kW}$ with $\mathrm{NH}_{3}-\mathrm{LiNO}_{3}$ using flat solar collectors in Madrid, Spain. The results showed that the equipment could operate about 6 hours of solar cooling at $-15^{\circ} \mathrm{C}$, obtaining a COP of 0.3 at a condensation temperature of $40^{\circ} \mathrm{C}$ of condensation temperature. The thermal fluid reached a maximum temperature of $100^{\circ} \mathrm{C}$ with a solar efficiency of 0.27 .

De Francisco et al. [9] carried out a test for the $\mathrm{NH}_{3}-\mathrm{H}_{2} \mathrm{O}$ absorption refrigeration system at $2 \mathrm{~kW}$. The generated heat was dissipating by natural convection in the absorber and condenser components and the system was manually controlled. The results showed that the COP obtained was very low (0.05); however, the authors concluded that it could be improved using forced convection.

Assim et al. [10] modeled an absorption chiller operated by hot water using an evacuated tube collector in TRNSYS software. It was found that the use of a hot water storage tank and a $12 \mathrm{~m}^{2}$ collector area were sufficient to maintain the room temperature at $26^{\circ} \mathrm{C}$ or below during the cooling season. Agrouaza et al. [11] studied a solar cooling system in several cities of Morocco and it was found that Errachindia city obtained the best average annual solar fraction $(30 \%)$ and a COP value of 0.33 . The COP values varied from 0.12 to 0.33 all across the year in other regions.

The $\mathrm{H}_{2} \mathrm{O}-\mathrm{LiBr}$ and $\mathrm{NH}_{3}-\mathrm{H}_{2} \mathrm{O}$ are the conventional working mixtures used in commercial absorption systems due to advantages in their thermodynamic properties. $\mathrm{H}_{2} \mathrm{O}-\mathrm{LiBr}$ obtained 
higher COP than the $\mathrm{NH}_{3}-\mathrm{H}_{2} \mathrm{O}$ system, though it has crystallization problems. The $\mathrm{NH}_{3}-\mathrm{LiNO}_{3}$ and $\mathrm{NH}_{3}-\mathrm{NaSCN}$ systems are a suitable alternative to $\mathrm{NH}_{3}-\mathrm{H}_{2} \mathrm{O}$ and both have the advantage of working either refrigeration or air conditioning [12], even though the values of COP are a little higher than the $\mathrm{NH}_{3}-\mathrm{H}_{2} \mathrm{O}$ system at a high generator temperature. Recently Gogoi and Knowar [13] carried out an energetic and energetic comparison with $\mathrm{H}_{2} \mathrm{O}-\mathrm{LiCl}$ and $\mathrm{H}_{2} \mathrm{O}-\mathrm{LiBr}$ systems under a similar working condition. They concluded that $\mathrm{H}_{2} \mathrm{O}-\mathrm{LiCl}$ obtained a higher $\mathrm{COP}$ than the $\mathrm{H}_{2} \mathrm{O}-\mathrm{LiBr}$ system. However, $\mathrm{H}_{2} \mathrm{O}-\mathrm{LiCl}$ has crystallization problems that depend on environmental temperature changes. Table 1 shows a comparison of working mixtures.

Table 1. Comparative data among working mixtures.

\begin{tabular}{ccccccc}
\hline Working Mixture & $\mathbf{C O P}{ }^{* 1}$ & $\mathbf{T}_{\mathbf{A C T}}{ }^{* 2}$ & Crystallization & Price ${ }^{* 3}(\mathrm{USD})$ & Pressure (Bar) & Refrigeration Condition \\
\hline $\mathrm{H}_{2} \mathrm{O}-\mathrm{LiBr}$ & 0.80 & low & medium & $131.35(\geq 99.0 \mathrm{wt} \%)$ & vacuum & no \\
$\mathrm{H}_{2} \mathrm{O}-\mathrm{LiCl}$ & 0.82 & low & high & $153.35(>99.0 \mathrm{wt} \%)$ & vacuum & no \\
$\mathrm{NH}_{3}-\mathrm{H}_{2} \mathrm{O}$ & 0.67 & medium & no & $193.45(>99.9 \mathrm{wt} \%)$ & $>10$ & yes \\
$\mathrm{NH}_{3}-\mathrm{LiNO}$ & 0.69 & medium & medium & $353.25(>99.0 \mathrm{wt} \%)$ & $>10$ & yes \\
$\mathrm{NH}_{3}-\mathrm{NaSCN}$ & 0.65 & medium & medium & $180.20(>98.0 \mathrm{wt} \%)$ & $>10$ & yes \\
\hline *1 Operation condition: $\mathrm{T}_{\mathrm{GE}}=75^{\circ} \mathrm{C}, \mathrm{T}_{\mathrm{AB}}=\mathrm{T}_{\mathrm{CO}}=35^{\circ} \mathrm{C}, \mathrm{T}_{\mathrm{EV}}=8{ }^{\circ} \mathrm{C} ; * 2 \mathrm{~T}_{\mathrm{ACT}}$ Activation temperature of the single \\
stage absorption chiller; ${ }^{* 3}$ Sigma-Aldrich, web page: www.sigmaaldrich.com.
\end{tabular}

Most papers published about the absorption cooling system mainly use only one working mixture in dynamic conditions. The objective of this paper was to carry out a thermodynamic analysis of an ACS using conventional $\left(\mathrm{NH}_{3}-\mathrm{H}_{2} \mathrm{O}\right.$ and $\left.\mathrm{H}_{2} \mathrm{O}-\mathrm{LiBr}\right)$ and unconventional $\left(\mathrm{NH}_{3}-\mathrm{LiNO}_{3}, \mathrm{NH}_{3}-\mathrm{NaSCN}\right.$, and $\mathrm{H}_{2} \mathrm{O}-\mathrm{LiCl}$ ) working mixtures based on the $\mathrm{COP}$ and the limitation on the crystallization of the solution for dynamic conditions.

\section{Description of the System}

The present study consists of the cooling of a building via a single stage absorption cooling system using evacuated solar collectors (SC) and an auxiliary system (AS), as shown in Figure 1. The auxiliary system is used to control the temperature coming from the solar collectors to the generator component (GE).

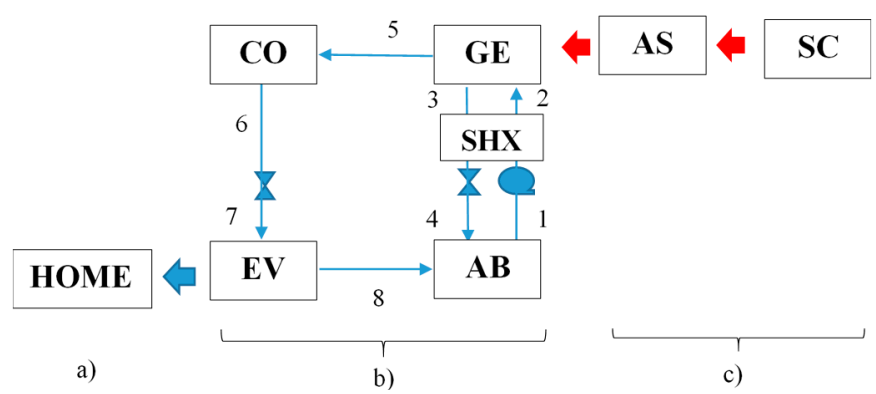

Figure 1. Diagram of the cooling system: (a) building; (b) absorption cooling system; and (c) solar collector and auxiliary system.

\section{Simulation of the Solar Cooling System}

The TRNSYS [14] software was used to simulate the solar absorption system for the cooling of a building located in Temixco City, Mexico. Figure 2 shows the schematic diagram of the process. There are two main circuits: solar collector (red line) and cooling (blue line). In the solar collector circuit, heating fluid (water) is pumped (Type 3d) from a storage tank (Type 4a) into the evacuated solar collector (Type $1 \mathrm{~b}$ ) and returned to the tank. This pump is controlled by Type $2 \mathrm{~b}$ and it is turned on when the output is higher than the input temperature of the solar collector; otherwise, it is turned off. In the cooling circuit, a heating fluid is sent to the auxiliary system (Type 66a) to control the supply 
temperature and enter towards to the generator component of the absorption cooling system (Type 66a-2). Finally, it is pumped by Type $3 \mathrm{~d}-2$ to the tank. The pump Type $3 \mathrm{~d}-2$ is controlled by Type $2 \mathrm{~b}-2$ and it is turned on when the building cooling load (Type 56) was activated to keep an indoor temperature below $25^{\circ} \mathrm{C}$. Type 66a and Type 66a-2 are programmed in Equation Engineering Solver (EES [15]) and both are coupled with the TRNSYS model for an hourly simulation.

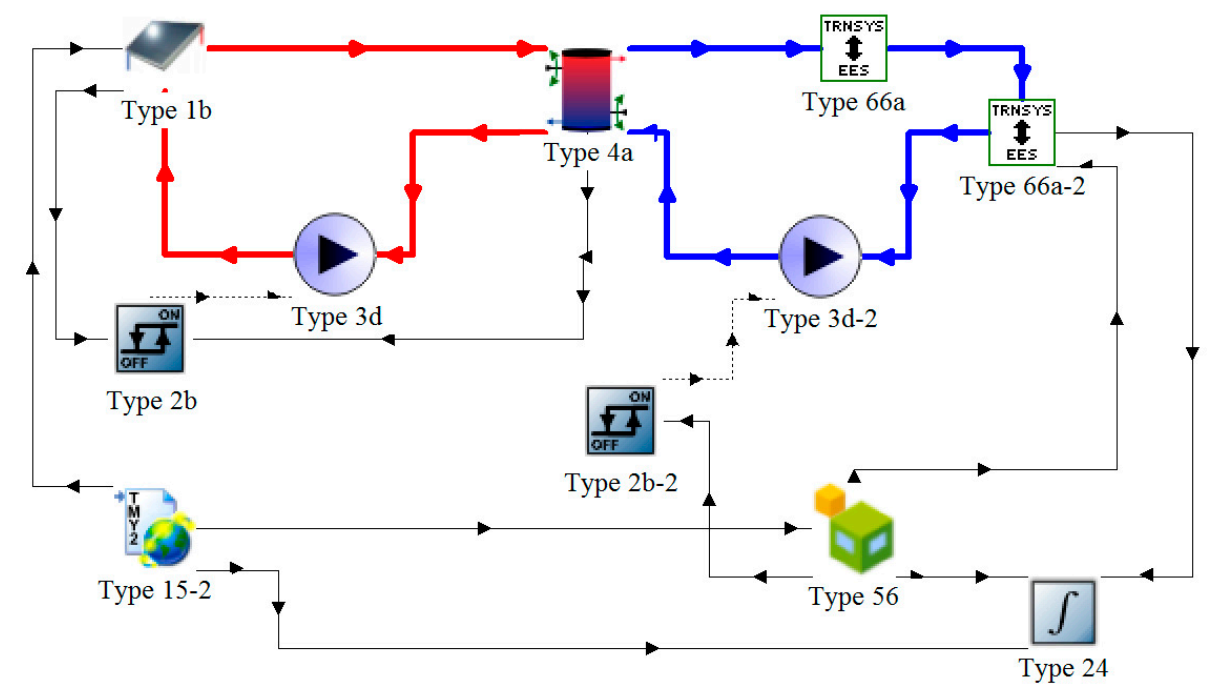

Figure 2. Diagram of the solar cooling system in TRaNsient SYstem Simulation (TRNSYS).

The TRNSYS software has incorporated modules (types) to model a single-effect absorption chiller from normalized data from catalogs of the manufacturer. However, $\mathrm{NH}_{3}-\mathrm{LiNO}_{3}, \mathrm{NH}_{3}-\mathrm{NaSCN}$, and $\mathrm{H}_{2} \mathrm{O}-\mathrm{LiCl}$ are still not available. Therefore, it was necessary to develop the mathematical model for each working mixture to simulate the ACS (Appendix A presents the basic equations, suppositions, and validation). The interaction between the Type 66a-2 and Type 56 consisted in: the instant cooling capacity of the building is equal to the evaporator component of the ACS. The operation of the ACS incorporated a heat transfer in the generator component of $\Delta \mathrm{T}=5^{\circ} \mathrm{C}$ between the supply and generator temperatures $\left(\mathrm{T}_{\mathrm{SUPPLY}}=\mathrm{T}_{\mathrm{GE}}+5^{\circ} \mathrm{C}\right)$ using water as the heating fluid. The heat transfer between the environment, and the condenser and absorber components involved a $\Delta \mathrm{T}=10^{\circ} \mathrm{C}\left(\mathrm{T}_{\mathrm{CO}}=\mathrm{T}_{\mathrm{AB}}=\mathrm{T}_{\mathrm{ENV}}\right.$ $+10^{\circ} \mathrm{C}$ ) cooled by air.

Type 66a is the auxiliary system and it was used to control the supply temperature to the ACS by using a heating $\left(\mathrm{Q}_{\mathrm{HS}}\right)$ or dissipating $\left(\mathrm{Q}_{\mathrm{DS}}\right)$ system.

The solar thermal collector efficiency (Type 1b) was calculated using a quadratic or linear efficiency equation according to ASHRAE or European standards. The solar collector is an HTP-Evacuated Tube HP-30SC [16] with a net aperture area of $3.86 \mathrm{~m}^{2}$. The cover is made of a glass vacuum tube and the absorber material is made of tube-copper and steel/plate-glass, with a tilt angle of $19^{\circ}$ (corresponding to the location latitude). The solar thermal collector efficiency is presented in Equation (1) [16],

$$
\eta=0.418-1.17 \frac{\left(\mathrm{T}_{\mathrm{IN}}-\mathrm{T}_{\mathrm{ENV}}\right)}{\mathrm{Q}_{\mathrm{RAD}}}
$$

where $\mathrm{T}_{\mathrm{IN}}$ and $\mathrm{T}_{\mathrm{ENV}}$ are the input temperatures of the solar collector and environment temperature, respectively, and $\mathrm{Q}_{\mathrm{RAD}}$ is the global radiation incident $\left(\mathrm{W} / \mathrm{m}^{2}{ }^{\circ} \mathrm{C}\right)$.

The Type 56 is a multi-zone building with 4 windows and only one zone, with some dimensions and main building characteristics shown in Table 2. Four occupants in a rest position and three computers turned on from 08:00 to 18:00 were considered as heat generation. 
Table 2. Building characteristics.

\begin{tabular}{cc}
\hline Concept & Quantity \\
\hline North and south wall & $35 \mathrm{~m}^{2}$ \\
Ceiling and floor & $75 \mathrm{~m}^{2}$ \\
West and east wall & $12.5 \mathrm{~m}^{2}$ \\
Thickness of walls & $0.12 \mathrm{~m} \mathrm{brick}$ \\
Windows & $1 \mathrm{~m}^{2}$ \\
Air change of ventilation & $6 \mathrm{~h}^{-1}$ \\
\hline
\end{tabular}

The Type 4a is a stratified storage tank. The properties and working conditions supplied were: a heat capacity of $4.19 \mathrm{~kJ} / \mathrm{kg} \mathrm{K}$, a height of $1 \mathrm{~m}$, an initial temperature of $70{ }^{\circ} \mathrm{C}$, and a loss coefficient $=$ $0.75 \mathrm{~W} / \mathrm{m}^{2} \mathrm{~K}$. The characteristics of the thermal insulation are: density $=16 \mathrm{~kg} / \mathrm{m}^{3}$, thickness $=0.05 \mathrm{~m}$ and, thermal conductivity $=0.05 \mathrm{~W} / \mathrm{m} \mathrm{K}$.

\section{The Mathematical Model of the Solar Cooling System}

\subsection{Assumptions}

- The pressure drops and heat losses are negligible for each pipeline.

- Fraction pump power (The energy converted to fluid thermal energy, fpar) was 0.05.

\subsection{Basic Equation (Energy and Mass Balances)}

This section presents a brief mathematical description [17] for each component model (Types).

The pump (Type 3d) computes a mass flow rate using a variable control function $(0 \leq \gamma \leq 1)$ and a fixed (user-specified) maximum flow capacity ( $\left.\mathrm{m}_{\mathrm{MAX}}\right)$.

$$
\begin{gathered}
\mathrm{m}_{\mathrm{IN}} \mathrm{C}_{\mathrm{p}}\left(\mathrm{T}_{\text {OUT }}-\mathrm{T}_{\mathrm{IN}}\right)=\mathrm{P} \text { fpar } \\
\mathrm{m}_{\text {OUT }}=\gamma \mathrm{m}_{\mathrm{MAX}}
\end{gathered}
$$

where fpar is the fraction pump power, $\mathrm{p}$ is the power $(\mathrm{kW}), \mathrm{m}_{\mathrm{OUT}}$ is the output mass flow rate $(\mathrm{kg} / \mathrm{s})$ and, $C_{p}$ is the heat capacity of the fluid $(\mathrm{kJ} / \mathrm{kg} \mathrm{K})$.

The solar collector (Type $1 \mathrm{~b}$ ) uses a general equation for solar thermal collector efficiency $(\eta)$ and it is calculated via Equations (4) and (5),

$$
\eta=\frac{Q_{U}}{A Q_{R A D}}=\frac{m_{p}\left(T_{\text {OUT }}-T_{I N}\right)}{A Q_{R A D}}
$$

where $\mathrm{QU}_{\mathrm{U}}$ is the useful heat of the solar collector $(\mathrm{W}), \mathrm{A}$ is the gross area $\left(\mathrm{m}^{2}\right)$ and, $\mathrm{Q}_{\mathrm{RAD}}$ is the global radiation incident on the solar collector $\left(\mathrm{W} / \mathrm{m}^{2}\right)$. Equation (4) can be rewritten as:

$$
\eta=a_{0}-a_{1} \frac{\left(T_{I N}-T_{E N V}\right)}{Q_{R A D}}-a_{2} \frac{\left(T_{I N}-T_{E N V}\right)^{2}}{Q_{R A D}}
$$

where the constants $\mathrm{a}_{0}, \mathrm{a}_{1}$ and $\mathrm{a}_{2}$ are, respectively, the intercept of the collector efficiency, the negative of the first-order coefficient and the negative of the second-order coefficient. The quadratic Equation (5) can be written as a linear Equation (1) with very similar results.

The stratified storage tank (Type 4a) can be modeled by assuming that the tank consists of $\mathrm{N}$ fully-mixed equal volume segments. An energy balance written in the ith tank segment (i) is expressed as:

$$
m_{i} C_{p, f} \frac{d T_{i}}{d t}=\alpha_{i} m_{h} C_{p, f}\left(T_{h}-T_{i}\right)+\beta_{i} m_{L} C_{p, f}\left(T_{L}-T_{i}\right)+U A_{i}\left(T_{E N V}-T_{i}\right)
$$


where $\mathrm{m}, \mathrm{T}$, and $\mathrm{t}$ are the mass flow rate, temperature and time, respectively. Subscripts $\mathrm{h}, \mathrm{L}$, and $\mathrm{f}$ are the solar collector, cooling auxiliary circuits and fluid, respectively (see Section 3), $\alpha_{\mathrm{i}}$ and $\beta_{\mathrm{i}}$ are a control function, and $U$ is the loss coefficient between the tank and its environment $\left(\mathrm{kW} / \mathrm{m}^{2}{ }^{\circ} \mathrm{C}\right)$.

The Quantity integrator (Type 24) integrates a series of quantities over a period of time using the following equation,

$$
Y_{i}=\int X_{i} d t
$$

where $X_{i}$ is the ith quantity to be integrated and $Y_{i}$ is the time integral of $X_{i}$

The multizone building (Type 56) models the thermal behavior of a building having multiple thermal zones, with the thermal capacity of the air volume and capacities which are closely connected with the air node (see Figure 3a). The convective heat that flows to the air node is calculated using Equation (8).

$$
\begin{aligned}
& Q_{i}=Q_{s u f, i}+Q_{\text {inf }, \mathrm{i}}+Q_{v e n t, i}+Q_{i c, i}+Q_{a f, i}+Q_{s o l a r, i}+Q_{a s r, i} \\
& \mathrm{Q}_{\text {surf,i }}=\mathrm{h}_{\mathrm{i}} \mathrm{A}\left(\mathrm{T}_{\text {surface, } \mathrm{i}}-\mathrm{T}_{\text {air }}\right)
\end{aligned}
$$

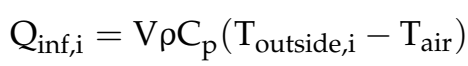

$$
\begin{aligned}
& \mathrm{Q}_{\mathrm{vent,i}}={\mathrm{V} \rho \mathrm{C}_{\mathrm{p}}}\left(\mathrm{T}_{\mathrm{ventilation,i}}-\mathrm{T}_{\text {air }}\right)
\end{aligned}
$$

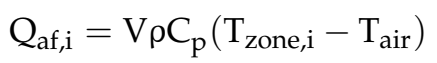

where the subscripts surf, inf, vent, ic, af, solar and asr are the energy gain for convective heat due to the: surfaces, infiltration (air flow from the outside only), ventilation (user-defined air flow), internal convective heat (people, equipment, radiator, etc.), the air flow from air node i or boundary condition, the fraction of solar radiation (due to the external windows) and the absorbed solar radiation on all internal shading devices that is directly transferred as a convective gain to the internal air, respectively.

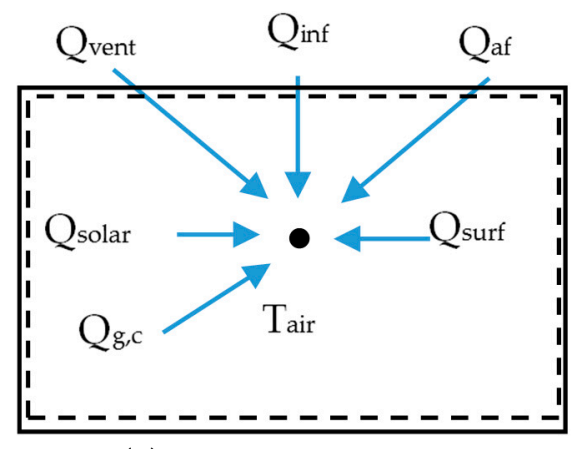

(a) Convective heat flows

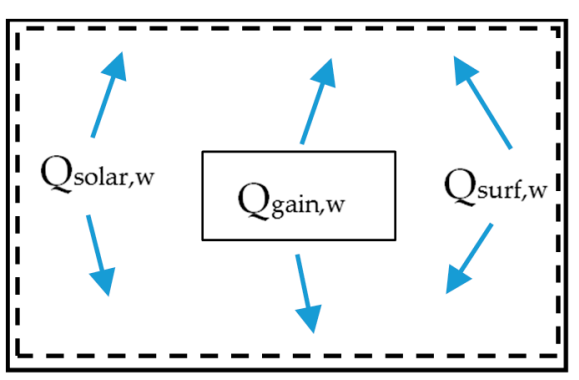

(b) Radiation heat flows

Figure 3. Heat flows in the building; (a) due to the convective heat; (b) due to the radiation.

The radiative heat flowing through the wall and window is calculated via Equation (13) (see Figure 3b),

$$
\mathrm{Q}_{\mathrm{w}, \mathrm{i}}=\mathrm{Q}_{\mathrm{surf}, \mathrm{w}, \mathrm{i}}+\mathrm{Q}_{\text {solar, } \mathrm{w}, \mathrm{i}}+\mathrm{Q}_{\text {long, } \mathrm{w}, \mathrm{i}}+\mathrm{Q}_{\mathrm{gain}, \mathrm{w}}
$$

where $Q_{w, i}$ represents the radiative gains for the wall surface temperature node, $Q_{\text {surf, } w, i}$ represents the radiative air node internal gains received by the wall, $Q_{\text {solar,w,i }}$ represents the solar gains through the zone windows received by the walls, $Q_{\text {long,w,i }}$ represents the longwave radiation exchange between this wall and all the other walls and windows, and $Q_{\text {gain,w }}$ represents the user-specified heat flow to the wall or window surface. All of these quantities are given in $\mathrm{kW}$.

The auxiliary system (Type 66a) is used to control the supply temperature ( $\left.\mathrm{T}_{\text {SUPPLY }}\right)$, when the storage tank temperature $\left(\mathrm{T}_{\mathrm{T}}\right)$ is lower than $\mathrm{T}_{\text {SUPPLY }}$ (obtained from Table 3); the heating system $\left(\mathrm{Q}_{\mathrm{HS}}\right)$ 
is activated using a simple energy balance (Equation (14)); otherwise, the dissipation system ( $\mathrm{Q}_{\mathrm{DS}}$ ) is activated and Equation (15) is applied to it:

$$
\begin{aligned}
& \mathrm{Q}_{\mathrm{HS}}=\mathrm{mC}_{\mathrm{p}}\left(\mathrm{T}_{\mathrm{T}}-\mathrm{T}_{\text {SUPPLY }}\right) \\
& \mathrm{Q}_{\text {Ds }}=\mathrm{mC}_{\mathrm{p}}\left(\mathrm{T}_{\text {SUPPLY }}-\mathrm{T}_{\mathrm{T}}\right)
\end{aligned}
$$

Table 3. Operation range of the supply temperature range for absorption cooling system (ACS).

\begin{tabular}{cllllllc}
\hline $\mathrm{T}_{\mathrm{CO}}=\mathrm{T}_{\mathrm{AB}},{ }^{\circ} \mathrm{C}$ & $<35$ & $<38$ & $<40$ & $<42$ & $<43$ & $<44$ \\
\hline $\mathrm{T}_{\text {SUPPLY }},{ }^{\circ} \mathrm{C}\left(\mathrm{NH}_{3}-\mathrm{H}_{2} \mathrm{O}\right)$ & $73-135$ & $80-135$ & $85-135$ & $90-135$ & $93-135$ & $96-135$ \\
$\mathrm{~T}_{\text {SUPPLY }},{ }^{\circ} \mathrm{C}\left(\mathrm{NH}_{3}-\mathrm{LiNO}{ }_{3}\right)$ & $70-35$ & $76-135$ & $81-135$ & $85-135$ & $86-135$ & $90-135$ \\
$\mathrm{~T}_{\text {SUPPLY }}{ }^{\circ} \mathrm{C}\left(\mathrm{NH}_{3}-\mathrm{NaSCN}\right)$ & $73-114$ & $80-121$ & $85-126$ & $90-129$ & $93-132$ & $95-133$ \\
$\mathrm{~T}_{\text {SUPPLY }},{ }^{\circ} \mathrm{C}\left(\mathrm{H}_{2} \mathrm{O}-\mathrm{LiBr}\right)$ & $72-90$ & $78-96$ & $83-100$ & $87-103$ & $90-106$ & $92-107$ \\
$\mathrm{~T}_{\text {SUPPLY }},{ }^{\circ} \mathrm{C}\left(\mathrm{H}_{2} \mathrm{O}-\mathrm{LiCl}\right)$ & $71-74$ & $77-81$ & $82-85$ & $86-88$ & $88-90$ & $91-92$ \\
\hline
\end{tabular}

The Differential controller (Type 2b) is an on/off differential controller that, can have a value of 1 or 0 . The value of the control signal is chosen as a function of the difference between upper (Th) and lower (Tl) temperatures, and both are compared with two dead-band temperature differences $\Delta \mathrm{Th}$ and $\Delta \mathrm{Tl}$. The new value of the control function depends on the value of the input control function at the previous time step.

The weather data processor (Type 15-2) serves the purpose of reading data at regular time intervals from an external weather data file, interpolating the data at time steps of less than one hour, and making it available for other TRNSYS components.

\subsection{Numerical Procedure}

The TRNSYS library includes many of the components commonly found in thermal and electrical energy systems, as well as component routines to handle input of weather data or other time-dependent forcing functions and output of simulation results. The default solver uses successive substitutions in order to solve the systems equations. The iterative numerical methods are based on a guess or initial values that are used as starting points for the iterations. If the system's equating is very complex it needs a good guess value [17].

EES software uses a variant of Newton's method [18] to solve systems of non-linear algebraic equations. The Jacobian matrix needed in Newton's method is evaluated numerically at each iteration. Sparse matrix techniques are employed to improve calculation efficiency and permit rather large problems to be solved in the limited memory of a microcomputer. The efficiency and convergence properties of the solution method are further improved by the step-size alteration and implementation of the blocking algorithm which breaks the problems into a number of smaller problems which are easier to solve. Several algorithms are implemented to determine the minimum or maximum value of a specified variable.

EES software supports Dynamic Data Exchange (DDE) commands in order to exchange information with other programs. DDE is a method of sending information to other programs through the Microsoft Windows operating system. Type 66 makes use of DDE commands to launch EES, pass parameter and input information to EES, and ask EES to solve and recuperate output information, which is then treated like the output from any other TRNSYS component [17].

\section{Operation Range of the Auxiliary System (AS)}

An analysis of the environment temperature was carried out in order to select the time of operation of the absorption cooling system (ACS). Type 15-2 was built in the TRNSYS software to simulate a year's environmental conditions obtained from meteorological data in Temixco city, Mexico. Figure 4 
shows the environment temperature and global radiation profiles across a year. The period from March to May (1460-3560 h) was selected to operate the absorption system due to the highest ambient temperature in a year (blue box). The maximum and minimum environment temperatures were 16.3 and $33.5{ }^{\circ} \mathrm{C}$, these conditions will be used to dissipate the heat load in the condenser and absorber components of the ACS. It is a limitation of the working operation because ACS could fall into the crystallization zone or low COP depending on the environmental temperature. COP is defined as the ratio of the energy absorbed in the evaporator to the energy supplied by the generator.

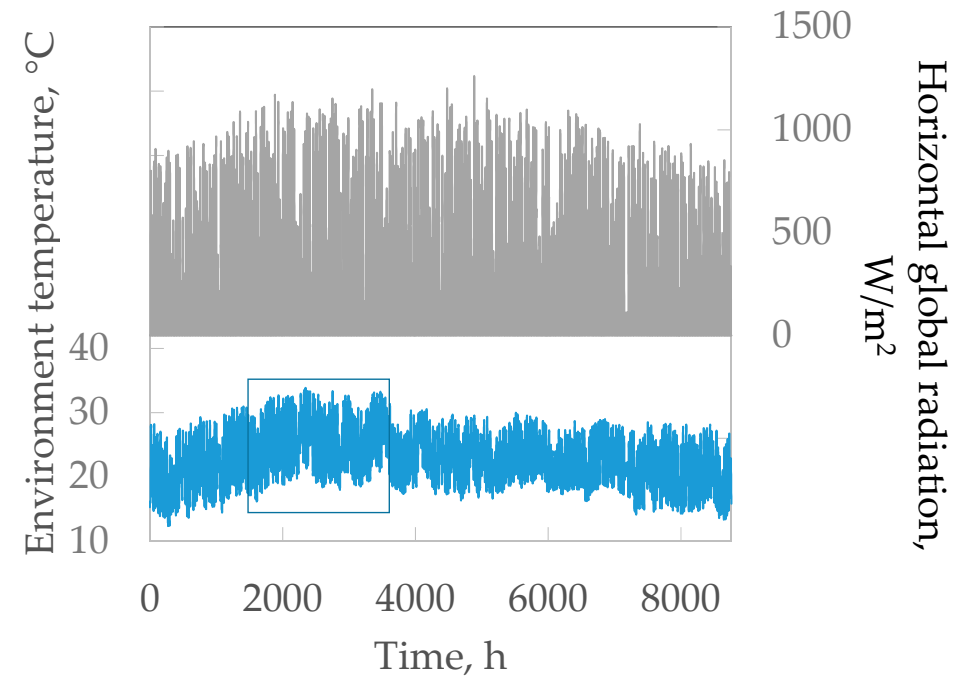

Figure 4. Environment temperature behavior along a year.

Figure 5 shows the minimum and maximum condenser and absorber temperatures that ACS will operate across the 3 months at $8{ }^{\circ} \mathrm{C}$ of the evaporator temperature. $\mathrm{H}_{2} \mathrm{O}-\mathrm{LiCl}$ obtained the highest $\mathrm{COP}$ (around 0.80-0.85) at $\mathrm{T}_{\mathrm{CO}}=\mathrm{T}_{\mathrm{AB}}=30^{\circ} \mathrm{C}$ and $\mathrm{NH}_{3}-\mathrm{H}_{2} \mathrm{O}$ obtained the lowest $\mathrm{COP}$ value (lower than 0.70). On the other hand, $\mathrm{H}_{2} \mathrm{O}-\mathrm{LiBr}$ obtained the highest $\mathrm{COP}$ (around 0.73) and $\mathrm{NH}_{3}-\mathrm{H}_{2} \mathrm{O}$ the lowest value (lower than 0.53) at $\mathrm{T}_{\mathrm{CO}}=\mathrm{T}_{\mathrm{AB}}=44^{\circ} \mathrm{C}$. It is clear that the increment of $\mathrm{T}_{\mathrm{CO}}$ and $\mathrm{T}_{\mathrm{AB}}$, decrease in the range of operation of ACS, mainly in the case of $\mathrm{H}_{2} \mathrm{O}-\mathrm{LiCl}$, and range of operation of the generator temperature is from 55 to $69{ }^{\circ} \mathrm{C}\left(\Delta \mathrm{T}=14{ }^{\circ} \mathrm{C}\right)$ and from 86 to $87^{\circ} \mathrm{C}\left(\Delta \mathrm{T}=1{ }^{\circ} \mathrm{C}\right)$ at a $\mathrm{T}_{\mathrm{CO}}=$ $\mathrm{T}_{\mathrm{AB}}$ of 30 and $44^{\circ} \mathrm{C}$, respectively.
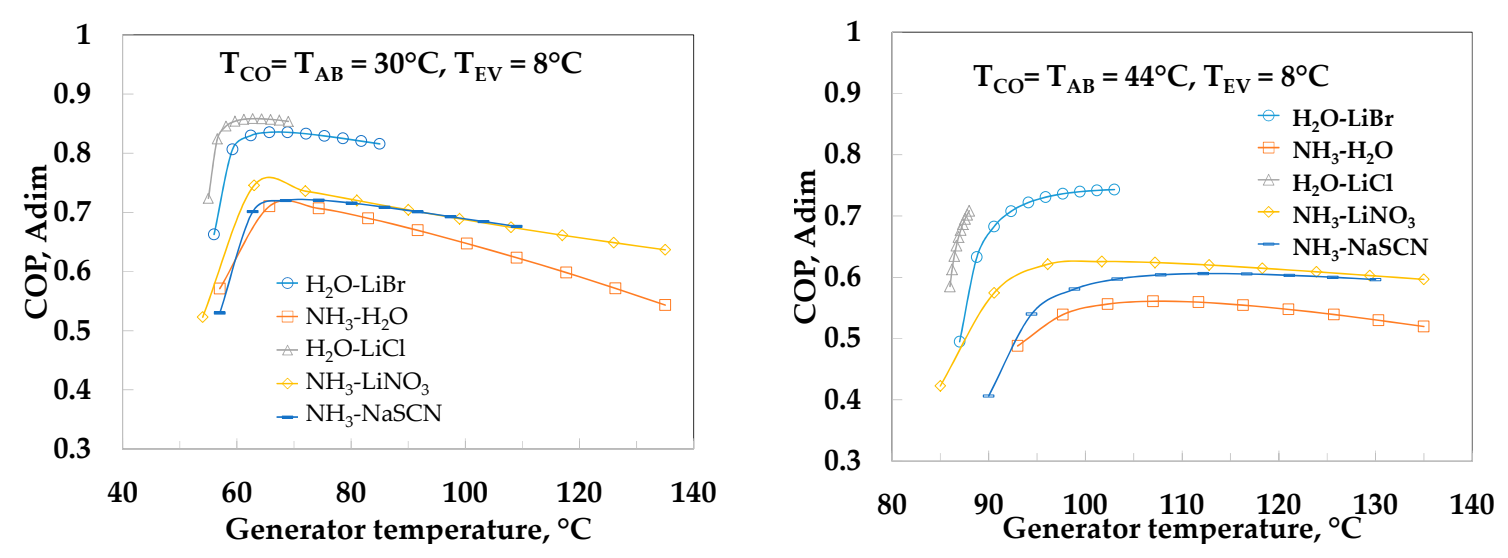

Figure 5. The coefficient of performance as a function of the generator temperature of an absorption cooling system. 
The $\mathrm{NH}_{3}-\mathrm{LiNO}_{3}$ and $\mathrm{NH}_{3}-\mathrm{NaSCN}$ system obtained similar $\mathrm{COP}$ values; however, $\mathrm{NH}_{3}-\mathrm{LiNO}_{3}$ has a wider operating range than the $\mathrm{NH}_{3}-\mathrm{NaSCN}$ system. Both mixtures obtained a COP of around 0.68 to 0.72 and 0.60 to 0.63 at $\mathrm{T}_{\mathrm{CO}}=\mathrm{T}_{\mathrm{AB}}=30$ and $44^{\circ} \mathrm{C}$, respectively.

Figure 6 shows the temperature as a function of the solution mass fraction for the absorber input, which is one of the streams most susceptible to fall in the crystallization zone (Point 4, from Figure 1b) corresponding to the same working condition in Figure 5. Crystallization temperatures are obtained mainly when the generator temperature obtained the maximum values; this means that the limit generator temperature is $82^{\circ}$ at $\mathrm{T}_{\mathrm{CO}}=\mathrm{T}_{\mathrm{AB}}=30^{\circ} \mathrm{C}$ in the case of the $\mathrm{H}_{2} \mathrm{O}-\mathrm{LiBr}$ that corresponds to a 0.67 mass fraction and to $45^{\circ} \mathrm{C}$ (Figure 6) located next to the crystallization line, as shown in Figure 7 .
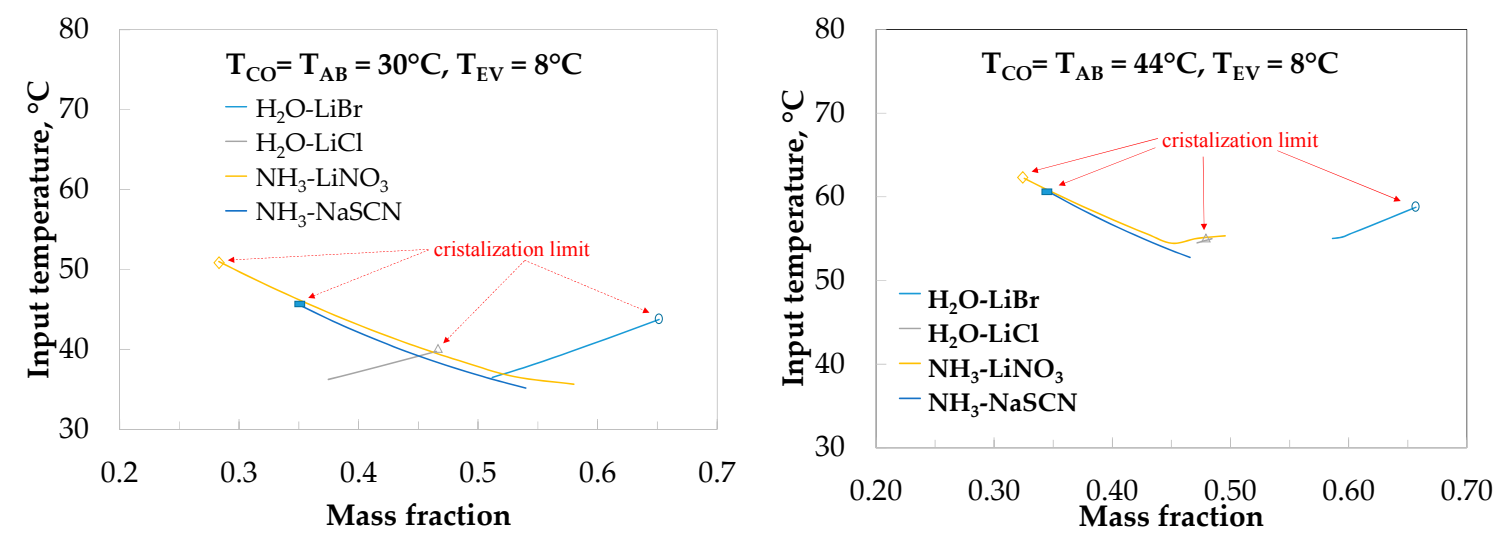

Figure 6. Temperature and solution concentrations for the absorber's input.

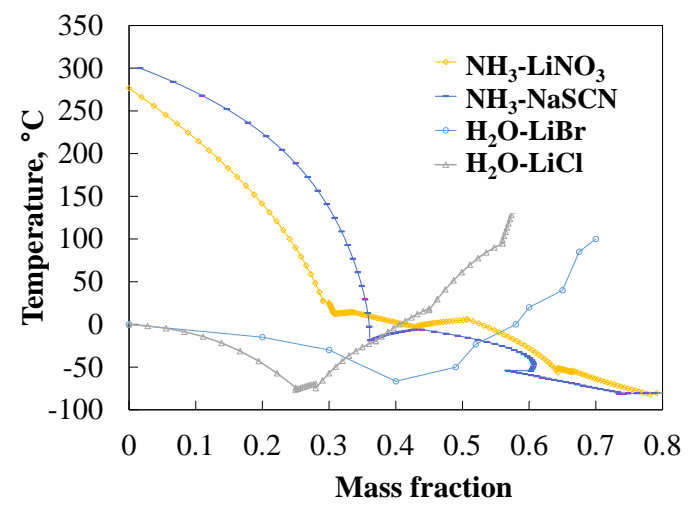

Figure 7. Crystallization curves for several working mixtures.

Note that the mass fraction for $\mathrm{H}_{2} \mathrm{O}-\mathrm{LiBr}$ and $\mathrm{H}_{2} \mathrm{O}-\mathrm{LiCl}$ are defined as the ratio of the mass of the absorbent to the mass of the solution, and $\mathrm{NH}_{3}-\mathrm{LiNO}_{3}$ and $\mathrm{NH}_{3}-\mathrm{NaSCN}$ are defined as the ratio of the mass of the refrigerant $\left(\mathrm{NH}_{3}\right)$ to the mass of the solution.

The Auxiliary system (Type 66a) controls the supply temperature of the ACS in a dynamic way because the storage tank $(\mathrm{T})$ and environment temperatures change throughout the day. When the supply temperature (see Table 3 ) was lower than the operation range, a heating system $\left(\mathrm{Q}_{\mathrm{HS}}\right)$ is turned on, when it was higher than operation range it is turned off and the dissipating heat system $\left(Q_{\mathrm{DH}}\right)$ is turned on. Table 3 shows the operation range of the supply temperature in order to obtain COP values of up to 0.4 or in order to avoid falling into the crystallization zone for each working mixture.

It was necessary to work at several ranges when working in the generator temperature because a wider temperature range limits its function due to the crystallization (except the $\mathrm{NH}_{3}-\mathrm{H}_{2} \mathrm{O}$ system); besides, $135^{\circ} \mathrm{C}$ was fixed as the maximum supply temperature. 


\section{Simulation Results}

The total cooling energy consumption of the building was $1.43 \times 10^{7} \mathrm{~kJ}$ evaluated during 3 months, fixing a maximum indoor temperature of $25^{\circ} \mathrm{C}$. This value was calculated using Type 24, which integrates the instant cooling capacity over the time interval of the summary. Figure 8 shows the behavior of indoor and environment temperatures and the cooling capacity from 2000 to $2160 \mathrm{~h}$ (one week); as can be seen the cooling capacity was turned off when the indoor temperature was lower than $25^{\circ} \mathrm{C}$.

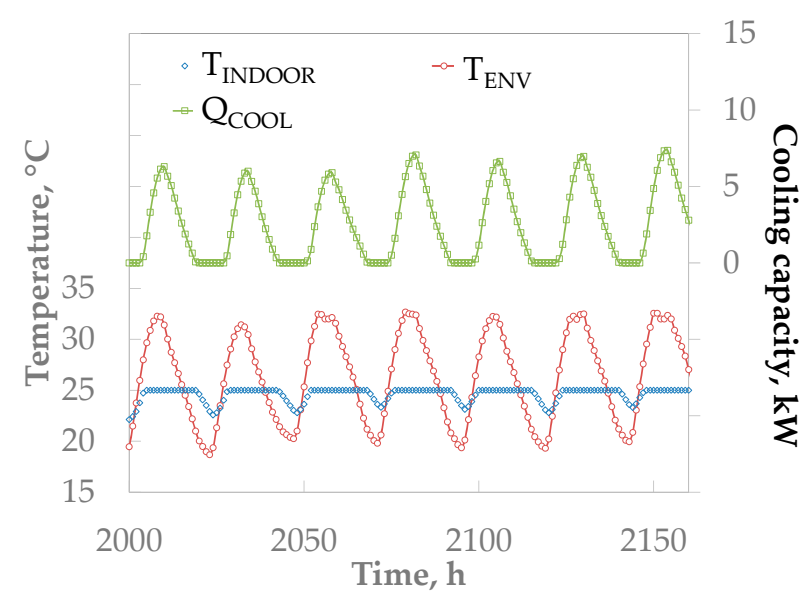

Figure 8. Indoor temperature and cooling capacity of the building.

The fractions of solar collector (SF), heating (HF), lost heat (LF) and Gain (GF) were the parameters we selected to compare each working mixture systems. They were defined in Equations (16)-(19) respectively.

$$
\begin{gathered}
\mathrm{SF}=\mathrm{Qt}_{\mathrm{SC}} / \mathrm{Qt} \mathrm{IN}_{\mathrm{N}} \\
\mathrm{HF}=\mathrm{Qt}_{\mathrm{HS}} / \mathrm{Qt} \mathrm{t}_{\mathrm{IN}} \\
\mathrm{LF}=\mathrm{Qt}_{\mathrm{LH}} / \mathrm{Qt} \mathrm{t}_{\mathrm{IN}} \\
\mathrm{GF}=\mathrm{Qt}_{\mathrm{SC}} /\left(\mathrm{Qt}_{\mathrm{HS}}+\mathrm{Qt}_{\mathrm{LH}}\right)
\end{gathered}
$$

$\mathrm{Qt}_{\mathrm{IN}}$ is the total energy input to the system due to the solar collectors ( $\mathrm{Qt}_{\mathrm{SC}}$ ) and heating system $\left(\mathrm{Qt}_{\mathrm{HS}}\right)$. $\mathrm{Qt} \mathrm{t}_{\mathrm{LH}}$ is the lost heat caused by the dissipating heat system $\left(\mathrm{Qt}_{\mathrm{DH}}\right)$ and the storage tank $\left(\mathrm{Qt}_{\mathrm{T}}\right)$.

Figure 9 shows the number of solar collectors as a function of energy fractions, fixing a storage tank volume of $2 \mathrm{~m}^{3}$ and a flow rate of $1000 \mathrm{~kg} / \mathrm{h}$ for pumps $\mathrm{P}_{1}$ and $\mathrm{P}_{2}$. A collector area of $42.5 \mathrm{~m}^{2}$ (11 solar collectors) was selected to compare each absorption system because this is the minimum number to satisfy the adequate relationship between the solar and heating fraction for all working mixtures. Note that the $\mathrm{H}_{2} \mathrm{O}-\mathrm{LiCl}$ system can be satisfied using $30 \mathrm{~m}^{2}$ of collector area. Moreover, the lost heat fraction (red line) has a constant value around 0.07 for all working mixtures with few solar collector areas. It was caused by the energy loss from the storage tank; however, when the solar collector is increased, the $\mathrm{LF}$ increases significantly, mainly for $\mathrm{H}_{2} \mathrm{O}-\mathrm{LiBr}$ and $\mathrm{H}_{2} \mathrm{O}-\mathrm{LiCl}$ systems, and this is because the dissipating heating system is activated. 

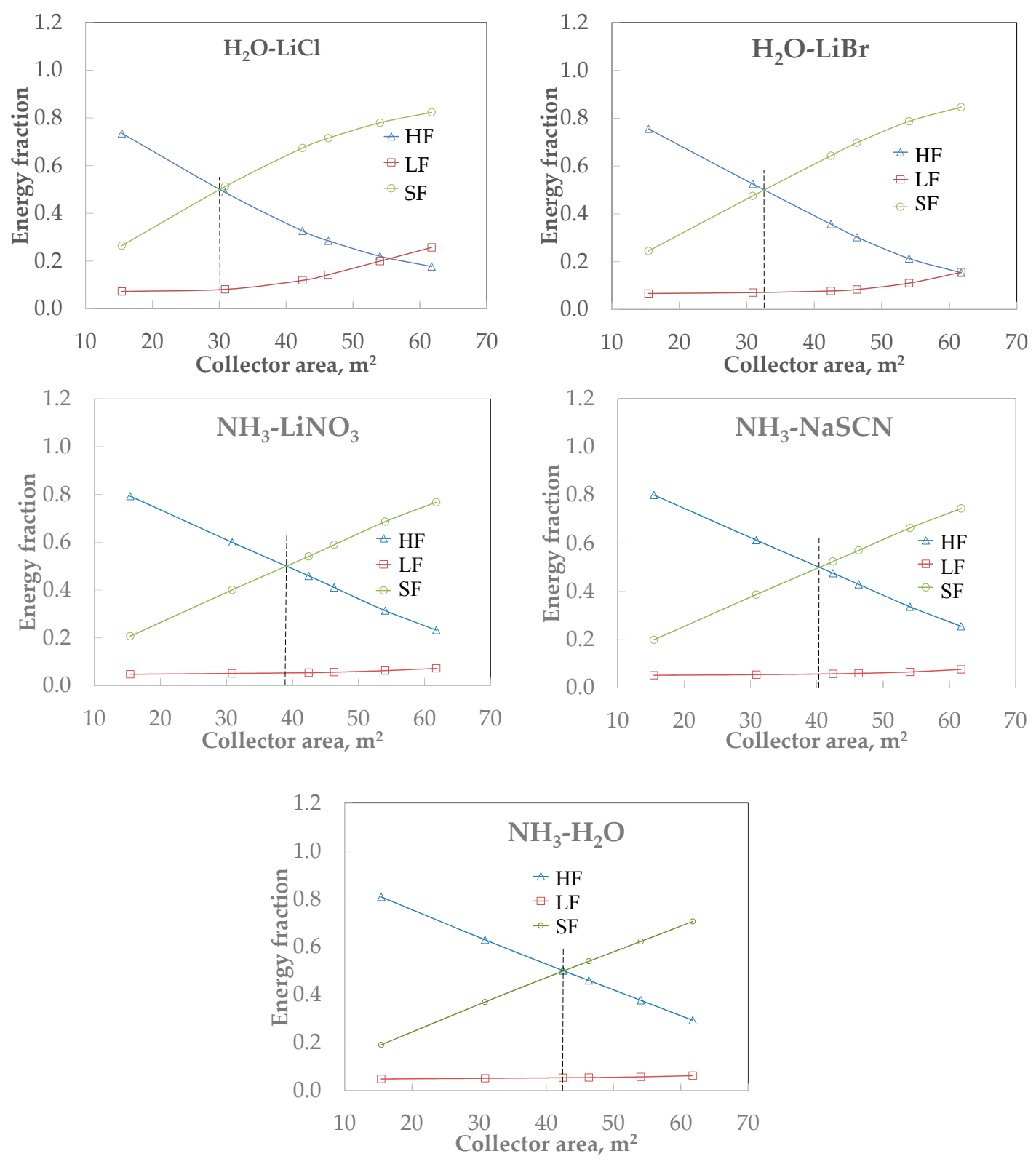

Figure 9. Energy fractions for each working mixture.

Figure 10 shows the COP behavior for each working mixture across one week from using 11 solar collectors $\left(42.5 \mathrm{~m}^{2}\right)$; as can be seen the $\mathrm{H}_{2} \mathrm{O}-\mathrm{LiCl}$ system obtained the highest $\mathrm{COP}$ value (around 0.78-0.86), $\mathrm{H}_{2} \mathrm{O}-\mathrm{LiBr}$ obtained $0.70-0.83$ and the $\mathrm{NH}_{3}-\mathrm{LiNO}_{3}, \mathrm{NH}_{3}-\mathrm{NaSCN}$ and $\mathrm{NH}_{3}-\mathrm{H}_{2} \mathrm{O}$ systems obtained around $0.50-0.71$.

Table 4 shows a resume of energy fractions evaluated over 3 months. The numbers that appear on the left side mean the best (1) and the worst (5) condition values. $\mathrm{H}_{2} \mathrm{O}-\mathrm{LiCl}$ obtained the maximum solar (0.67) and minimum heating (0.33) fraction; however, it obtained the maximum (0.12) lost heat fraction. This last value means that $12 \%$ of the energy supplied ( $\left.\mathrm{Q}_{\mathrm{IN}}\right)$ was lost in the storage tank and the dissipating heat system. Note that $\mathrm{SF}+\mathrm{HF}=1$. 


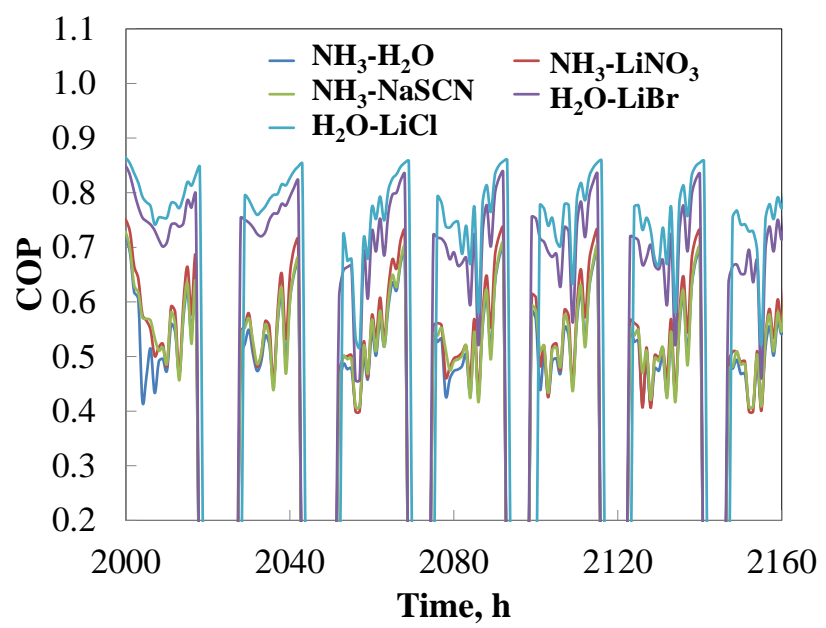

Figure 10. The coefficient of performance as a function of time.

Table 4. Resume of energy fractions for all working mixtures.

\begin{tabular}{ccccc}
\hline Working Mixture & Solar Collector Area & SF & HF & LF \\
\hline $\mathrm{H}_{2} \mathrm{O}-\mathrm{LiCl}$ & 42.5 & $(1) 0.67$ & $(1) 0.33$ & (5) 0.12 \\
$\mathrm{H}_{2} \mathrm{O}-\mathrm{LiBr}$ & 42.5 & $(2) 0.64$ & $(2) 0.36$ & (4) 0.08 \\
$\mathrm{NH}_{3}-\mathrm{LiNO}$ & 42.5 & $(3) 0.54$ & $(3) 0.46$ & $(1) 0.05$ \\
$\mathrm{NH}_{3}-\mathrm{NaSCN}_{\mathrm{NH}_{3}-\mathrm{H}_{2} \mathrm{O}}^{42.5}$ & $(4) 0.52$ & $(3) 0.48$ & (3) 0.06 \\
& 42.5 & $(5) 0.50$ & $(5) 0.50$ & (1) 0.05 \\
\hline
\end{tabular}

Table 5 shows the total energy of the solar collector $\left(Q t_{S C}\right)$, heating $\left(\mathrm{Qt}_{\mathrm{HS}}\right)$, storage tank $\left(\mathrm{Q} \mathrm{t}_{\mathrm{LH}, \mathrm{T}}\right)$ and dissipation heat $\left(\mathrm{Qt}_{\mathrm{LH}, \mathrm{D}}\right)$ evaluated during 3 months for each working mixture using $42.5 \mathrm{~m}^{2}$ of collector area. The $\mathrm{NH}_{3}-\mathrm{LiNO}_{3}$ system obtained the maximum value of energy from solar collectors $\left(2.13 \times 10^{7} \mathrm{~kJ}\right)$ and the $\mathrm{H}_{2} \mathrm{O}$ - $\mathrm{LiBr}$ system was the worst $\left(2.04 \times 10^{7} \mathrm{~kJ}\right)$. It was caused because the $\mathrm{H}_{2} \mathrm{O}-\mathrm{LiBr}$ system obtained a better COP value than the $\mathrm{NH}_{3}-\mathrm{LiNO}_{3}$ system; therefore, the storage tank temperature starts to increase, reducing the solar collector efficiency.

Table 5. Total energy using 11 solar collectors $\left(42.5 \mathrm{~m}^{2}\right)$.

\begin{tabular}{|c|c|c|c|c|}
\hline Working Mixture & $\mathrm{Qt}_{\mathrm{SC}}(\mathrm{kJ})$ & $\mathrm{Qt}_{\mathrm{HS}}(\mathbf{k J})$ & $\mathrm{Qt}_{\mathrm{LH}, \mathrm{T}}(\mathrm{kJ})$ & $\mathrm{Qt}_{\mathrm{LH}, \mathrm{D}}(\mathrm{kJ})$ \\
\hline $\mathrm{H}_{2} \mathrm{O}-\mathrm{LiCl}$ & (4) $2.07 \times 10^{7}$ & (1) $9.99 \times 10^{6}$ & (4) $2.33 \times 10^{6}$ & (5) $1.31 \times 10^{6}$ \\
\hline $\mathrm{H}_{2} \mathrm{O}-\mathrm{LiBr}$ & (5) $2.04 \times 10^{7}$ & (2) $1.13 \times 10^{7}$ & (5) $2.42 \times 10^{6}$ & (4) $4.04 \times 10^{4}$ \\
\hline $\mathrm{NH}_{3}-\mathrm{LiNO}_{3}$ & (1) $2.13 \times 10^{7}$ & (3) $1.81 \times 10^{7}$ & (1) $2.14 \times 10^{6}$ & (1) 0.0 \\
\hline $\mathrm{NH}_{3}-\mathrm{NaSCN}$ & (3) $2.08 \times 10^{7}$ & (4) $1.89 \times 10^{7}$ & (3) $2.31 \times 10^{6}$ & (1) 0.0 \\
\hline $\mathrm{NH}_{3}-\mathrm{H}_{2} \mathrm{O}$ & (2) $2.09 \times 10^{7}$ & (5) $2.10 \times 10^{7}$ & (2) $2.26 \times 10^{6}$ & (1) 0.0 \\
\hline
\end{tabular}

The $\mathrm{H}_{2} \mathrm{O}$ - $\mathrm{LiCl}$ and $\mathrm{H}_{2} \mathrm{O}-\mathrm{LiBr}$ systems obtained the minimum consumption of heating energy $\left(9.99 \times 10^{6} \mathrm{~kJ}\right.$ and $1.13 \times 10^{7} \mathrm{~kJ}$, respectively), while the $\mathrm{NH}_{3}-\mathrm{H}_{2} \mathrm{O}$ system obtained the maximum value $\left(2.10 \times 10^{7} \mathrm{~kJ}\right)$ because these systems can operate at a lower generator temperature than the $\mathrm{NH}_{3}-\mathrm{H}_{2} \mathrm{O}$ system.

The lost energy was caused mainly by the storage tank. The $\mathrm{NH}_{3}-\mathrm{LiNO}_{3}$ system obtained the lowest value of lost energy in the storage tank $\left(2.14 \times 10^{6} \mathrm{~kJ}\right)$ and $\mathrm{H}_{2} \mathrm{O}$-LiBr obtained the highest $\left(2.42 \times 10^{6} \mathrm{~kJ}\right)$, caused by the highest storage tank temperature. The lost energy due to the dissipating system was only activated for the $\mathrm{H}_{2} \mathrm{O}-\mathrm{LiCl}$ and $\mathrm{H}_{2} \mathrm{O}-\mathrm{LiBr}$ systems.

Figures 11 and 12 show the effect volume and the thickness of the insulator of the storage tank on the solar and heating fraction, respectively. The increment of the tank volume slightly lowers the values of SF, which positively affects the HF values. 

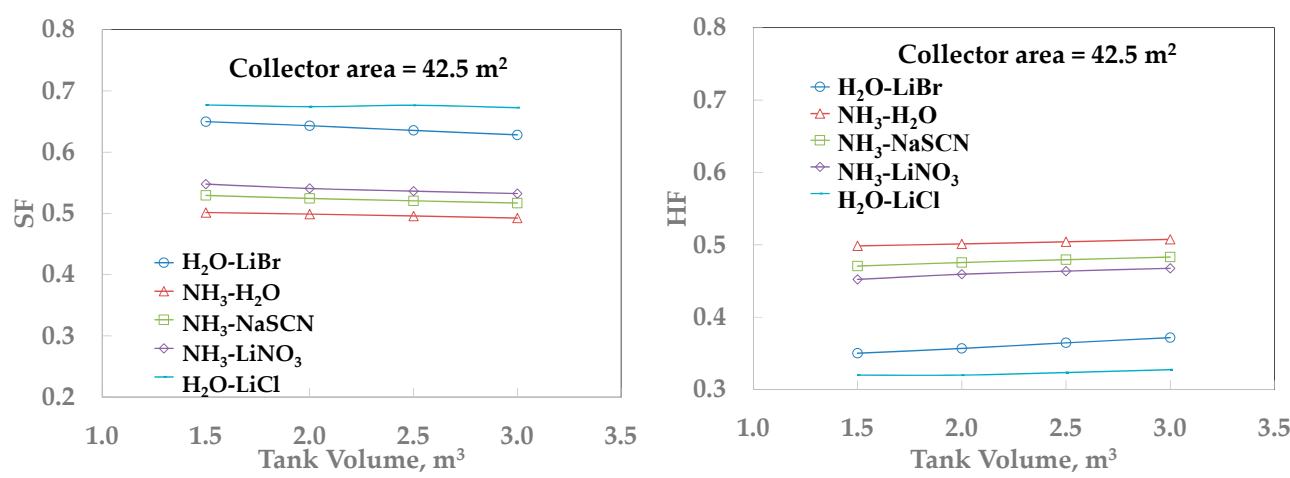

Figure 11. The energy fraction as a function of the volume tank using different working mixtures.
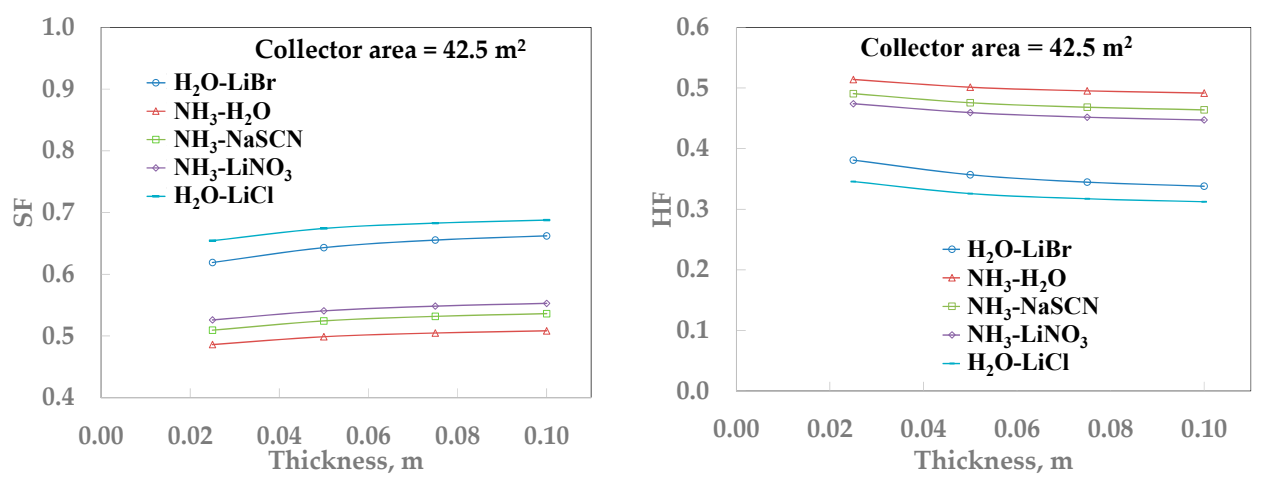

Figure 12. The energy fraction as a function of the insulation thickness of the storage tank.

The increment of the insulation thickness of the tank positively affects the solar fraction and negatively affects the heating fraction. Moreover, when the insulation thickness was higher than 0.08 $\mathrm{m}$, the energy fractions were slightly affected by it.

Figure 13 shows that the increments of the solar collector area, the solar and lost heat fraction increase too. The maximum SF obtained was around 0.90 for the $\mathrm{H}_{2} \mathrm{O}-\mathrm{LiBr}$ and $\mathrm{H}_{2} \mathrm{O}-\mathrm{LiCl}$ systems using $77.20 \mathrm{~m}^{2}$ of collector area and was 0.94 for the other working mixtures using $108.1 \mathrm{~m}^{2}$ of collector area. After these values, the increment of the solar collector area will affect softly to the SF because the dissipation heat system is activated to avoid crystallization problems or COP values lower than 0.4 and because the generator temperature was limited to $135^{\circ} \mathrm{C}$.
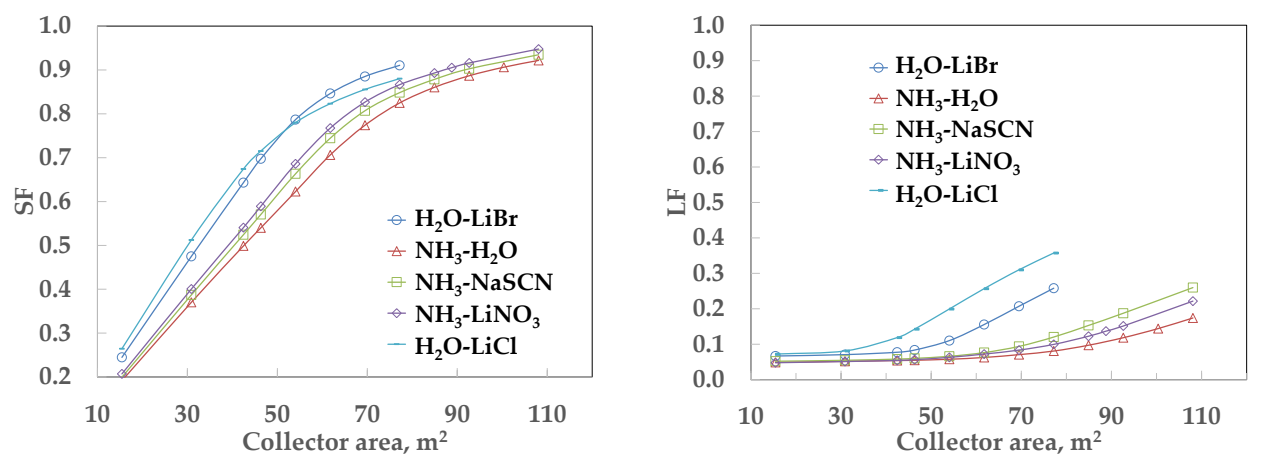

Figure 13. The energy fraction as a function of the number of solar collectors using different working mixtures.

The solar fraction shows a linear behavior from 15 to $50 \mathrm{~m}^{2}$ of collector area for all working mixtures, after which the increment shows a logarithmic behavior because the energy lost (LF) starts 
to increase due to the dissipation system. In order to select the adequate number of solar collectors for each working mixture, a maximization of the gain fraction (GF) parameter was carried out. This parameter represents the best relationship between the solar energy and the energy that is "not desirable" (the heating system and lost heat from the storage tank and dissipation system). Each working system obtained a maximum value of $\mathrm{GF}$ of 2.3, 3.8, 4.7, 6.1 and 6.6 for the $\mathrm{H}_{2} \mathrm{O}-\mathrm{LiCl}, \mathrm{H}_{2} \mathrm{O}-\mathrm{LiBr}$, $\mathrm{NH}_{3}-\mathrm{NaSCN}, \mathrm{NH}_{3}-\mathrm{H}_{2} \mathrm{O}$ and $\mathrm{NH}_{3}-\mathrm{LiNO}_{3}$ systems, respectively as is shown in Figure 14. Table 6 shows the number of solar collectors for each working mixture system and the energy fractions based on the GF. The $\mathrm{H}_{2} \mathrm{O}-\mathrm{LiCl}$ system obtained the minimum solar collector area $\left(54.0 \mathrm{~m}^{2}\right)$, however, it obtained the maximum lost heat fraction (0.20) and the lowest solar fraction value (0.78). It was caused by the short working operation due to the crystallization problem. Meanwhile, the $\mathrm{NH}_{3}-\mathrm{LiNO}_{3}$ and $\mathrm{NH}_{3}-\mathrm{H}_{2} \mathrm{O}$ systems obtained the maximum solar (0.91) and minimum heating (0.09) fraction, using an area solar collector of 88.8 and $100.4 \mathrm{~m}^{2}$, respectively. This means that this system could operate at a higher solar collector number with low lost energy.

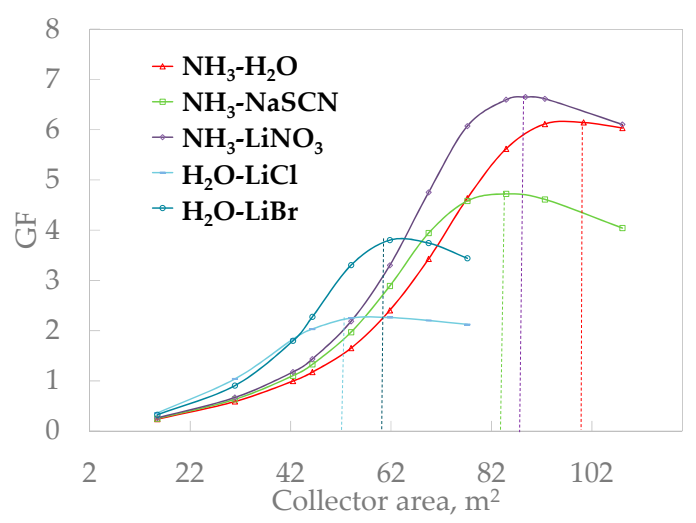

Figure 14. The gain fraction as a function of the number of solar collectors using different working mixtures.

Table 6. Results of energy fractions.

\begin{tabular}{ccccccc}
\hline Working Mixture & GF & No. of Solar Collector & Solar Collector Area $\left(\mathbf{m}^{2}\right)$ & SF & HF & LF \\
\hline $\mathrm{H}_{2} \mathrm{O}-\mathrm{LiCl}$ & 2.3 & 14 & 54.0 & 0.78 & 0.22 & 0.20 \\
$\mathrm{H}_{2} \mathrm{O}-\mathrm{LiBr}$ & 3.8 & 16 & 61.8 & 0.85 & 0.15 & 0.16 \\
$\mathrm{NH}_{3}-\mathrm{NaSCN}$ & 4.7 & 17 & 84.9 & 0.88 & 0.12 & 0.15 \\
$\mathrm{NH}_{3}-\mathrm{H}_{2} \mathrm{O}$ & 6.1 & 26 & 100.4 & 0.91 & 0.09 & 0.14 \\
$\mathrm{NH}_{3}-\mathrm{LiNO}_{3}$ & 6.6 & 23 & 88.8 & 0.91 & 0.09 & 0.14 \\
\hline
\end{tabular}

\section{Conclusions}

This paper presented a thermal analysis of the absorption cooling system with different working mixtures in a dynamic condition for conditioning a building located in Temixco, Mexico using TRNSYS and EES software. In this study, we analyzed the behavior of the system as a function of the number of evacuated solar collectors and the volume of the storage tank. The following conclusions are presented:

- The COP of the absorption cooling system analyzed the condenser and absorber temperatures at 30 and $44{ }^{\circ} \mathrm{C}$ at a fixed evaporator temperature of $8{ }^{\circ} \mathrm{C}$, in order to select the operation range of the generator temperature to avoid obtaining values lower than 0.4 for the COP and crystallization zone, after which different condenser and absorber temperature ranges were set.

- A solar collector area of $42.5 \mathrm{~m}^{2}$ was selected to carry out the thermal analysis because it presented the adequate relationship between the energy fraction of the heating system and the solar collectors. The $\mathrm{H}_{2} \mathrm{O}-\mathrm{LiCl}$ system obtained the maximum solar fraction (0.67) and the minimum heating fraction (0.33); however, it obtained the maximum lost heat fraction (0.12), in spite of obtaining the best $\mathrm{COP}$ among the other working mixtures. The $\mathrm{NH}_{3}-\mathrm{LiNO}_{3}$ system 
obtained the maximum value of energy from solar collectors $\left(2.13 \times 10^{7} \mathrm{~kJ}\right)$ and the $\mathrm{H}_{2} \mathrm{O}-\mathrm{LiBr}$ system was the worst $\left(2.04 \times 10^{7} \mathrm{~kJ}\right)$ because it obtained a better $\mathrm{COP}$ than the $\mathrm{NH}_{3}-\mathrm{LiNO}_{3}$ system. Therefore, the storage tank temperature starts to increase, reducing the solar collector efficiency.

- The increment of the tank volume decreases the values of SF slightly, which positively affects the HF values. On the other hand, the increment of the insulation thickness of the tank positively affects the solar fraction and negatively affects the heating fraction. Moreover, when the insulation thickness was higher than $0.08 \mathrm{~m}$, the energy fractions were slightly affected by it.

- The maximum solar fraction obtained was around 0.90 for the $\mathrm{H}_{2} \mathrm{O}-\mathrm{LiBr}$ and $\mathrm{H}_{2} \mathrm{O}-\mathrm{LiCl}$ systems using $77.20 \mathrm{~m}^{2}$ of collector area and was 0.94 for the other working mixtures using $108.1 \mathrm{~m}^{2}$ of collector area. This is because the dissipation heat system was activated to avoid crystallization problems or COP values lower than 0.4 and because the generator temperature was limited to $135^{\circ} \mathrm{C}$.

- A gains fraction was used to select the adequate solar collector number for each working mixture. This parameter represents the energy fraction between the solar collectors and the heating system and lost heat. The $\mathrm{H}_{2} \mathrm{O}-\mathrm{LiCl}$ system obtained the minimum GF (2.3), with a solar collector area of $54.0 \mathrm{~m}^{2}$ (14 solar collectors). It was caused by a short working operation resulting from the crystallization problem. On the other hand, $\mathrm{NH}_{3}-\mathrm{LiNO}_{3}$ and $\mathrm{NH}_{3}-\mathrm{H}_{2} \mathrm{O}$ obtained the highest GF (up 6), both obtained the maximum solar (0.91) and minimum heating (0.09) fractions, respectively, using 88.8 and $100.4 \mathrm{~m}^{2}$ of the solar collector area, respectively.

Acknowledgments: The authors gratefully acknowledge the Red SUMAS (CONACYT Ref. 271624) and PRODEP (UAEMOR-PTC-382) projects for providing software EES and TRNSYS, and the Instituto de Energías Renovables of the UNAM for meteorology data.

Author Contributions: Rosenberg Romero, Antonio Rodriguez and Jonathan Ibarra Bahena carried out the mathematical model of the ACS for all working mixtures in EES software and Jesus Cerezo, Alexis Acuña and Gisela Montero carried out the simulation of the solar absorption cooling system in TRNSYS software.

Conflicts of Interest: The authors declare no conflict of interest.

\section{Nomenclature}

$\begin{array}{ll}\text { A } & \text { area, } \mathrm{m}^{2} \\ \mathrm{ACS} & \text { absorption cooling system } \\ \mathrm{AS} & \text { auxiliary system } \\ \mathrm{COP} & \text { coefficient of performance, adim } \\ \mathrm{C}_{\mathrm{p}} & \text { heat capacity, } \mathrm{kJ} / \mathrm{kg}^{\circ} \mathrm{C} \\ \mathrm{m} & \text { mass flow rate, } \mathrm{kg} / \mathrm{s} \\ \mathrm{Q} & \text { heat load, } \mathrm{kW} \\ \mathrm{Qt} & \text { total energy, } \mathrm{kJ} \\ \mathrm{SC} & \text { solar collector } \\ \mathrm{SHX} & \text { solution heat exchanger } \\ \mathrm{T} & \text { temperature, }{ }^{\circ} \mathrm{C} \\ \mathrm{t} & \text { time, } \mathrm{s} \\ \mathrm{U} & \text { loss coefficient between the tank and its environment, } \mathrm{kW} / \mathrm{m}^{2}{ }^{\circ} \mathrm{C} \\ \mathrm{h} & \text { specific enthalpy, } \mathrm{kJ} / \mathrm{kg} \\ \mathrm{x} & \text { liquid ammonia concentration, } \% \text { by weight } \\ \mathrm{y} & \text { vapor ammonia concentration, } \% \text { by weight }\end{array}$




$\begin{array}{ll}\text { Subscripts } & \\ \text { AB } & \text { absorber } \\ \text { CO } & \text { condenser } \\ \text { COOL } & \text { cooling } \\ \text { DH } & \text { dissipating system } \\ \text { ENV } & \text { environment } \\ \text { GE } & \text { generator } \\ \text { HS } & \text { heating system } \\ \text { HS } & \text { heating system } \\ \text { IN } & \text { input } \\ \text { LH } & \text { lost heat } \\ \text { OUT } & \text { output } \\ \text { RAD } & \text { radiation } \\ \text { SC } & \text { solar collector } \\ \text { Symbols } & \\ \eta & \text { efficiency } \\ \alpha & \text { control function for solar collector circuit } \\ \beta & \text { control function for cooling circuit }\end{array}$

\section{Appendix A.}

This section describes the mathematical model of the single stage absorption cooling system to evaluate the coefficient of performance for each working mixture as well as its validation.

\section{Appendix A.1. Simulation Model}

The ACS (Figure 1b) simulation was based on simple mass and energy balances for each component [19] programmed in the EES software. The suppositions are described as follows:

1. The system operates under steady-state conditions.

2. The pressure drops and heat losses are negligible for each component and pipeline.

3. Expansion valves are adiabatic and isenthalpic.

4. The efficiency $\left(\mathrm{ES}_{\mathrm{HX}}\right)$ of the solution heat exchanger (SHX) is 0.8.

5. The saturated condition at the condenser, evaporator, generator and absorber outlets.

6. The vapor (Point 5 from Figure 1) and solution (3) streams have the same temperature at the generator outlet.

7. The refrigerant is considered pure in the evaporator.

8. The power of the pump is negligible.

Appendix A.2. Energy Balances

Absorber

$$
\begin{gathered}
\mathrm{m}_{1}=\mathrm{m}_{4}+\mathrm{m}_{8} \\
\mathrm{~m}_{1} \mathrm{x}_{1}=\mathrm{m}_{4} \mathrm{x}_{4}+\mathrm{m}_{8} \mathrm{y}_{8} \\
\mathrm{~m}_{1} \mathrm{~h}_{1}+\mathrm{Q}_{\mathrm{AB}}=\mathrm{m}_{4} \mathrm{~h}_{4}+\mathrm{m}_{8} \mathrm{~h}_{8}
\end{gathered}
$$

Generator

$$
\begin{gathered}
\mathrm{m}_{2}=\mathrm{m}_{3}+\mathrm{m}_{5} \\
\mathrm{~m}_{2} \mathrm{x}_{2}=\mathrm{m}_{3} \mathrm{x}_{3}+\mathrm{m}_{5} \mathrm{y}_{5} \\
\mathrm{~m}_{2} \mathrm{~h}_{2}+\mathrm{Q}_{\mathrm{GE}}=\mathrm{m}_{3} \mathrm{~h}_{3}+\mathrm{m}_{5} \mathrm{~h}_{5}
\end{gathered}
$$

Condensador

$$
\begin{gathered}
\mathrm{m}_{5}=\mathrm{m}_{6} \\
\mathrm{~m}_{5} \mathrm{~h}_{5}=\mathrm{m}_{6} \mathrm{~h}_{6}+\mathrm{Q}_{\mathrm{CO}}
\end{gathered}
$$

Evaporador

$$
\begin{gathered}
\mathrm{M}_{7}=\mathrm{m}_{8} \\
\mathrm{M}_{7} \mathrm{~h}_{7}+\mathrm{Q}_{\mathrm{EV}}=\mathrm{m}_{8} \mathrm{~h}_{8}
\end{gathered}
$$

Economizer (SHX)

$$
\mathrm{Q}_{\mathrm{MAX} 1}=\mathrm{m}_{1} \mathrm{C}_{\mathrm{p}, 1}\left(\mathrm{~T}_{3}-\mathrm{T}_{1}\right)
$$




$$
\begin{gathered}
\mathrm{Q}_{\mathrm{MAX} 3}=\mathrm{m}_{3} \mathrm{C}_{\mathrm{p}, 3}\left(\mathrm{~T}_{3}-\mathrm{T}_{1}\right) \\
\mathrm{Q}_{\mathrm{MIN}}=\operatorname{MIN}\left(\mathrm{Q}_{\mathrm{MAX}}, \mathrm{Q}_{\mathrm{MAX} 5}\right) \\
\mathrm{Q}_{\mathrm{SHX}}=\mathrm{ES}_{\mathrm{HX}} \mathrm{Q}_{\mathrm{MIN}} \\
\mathrm{h}_{2}=\mathrm{Q}_{\mathrm{SHX}} / \mathrm{m}_{1}+\mathrm{h}_{1} \\
\mathrm{~h}_{4}=\mathrm{h}_{3}-\mathrm{Q}_{\mathrm{SHX}} / \mathrm{m}_{3} \\
\mathrm{~m}_{1} \mathrm{~h}_{1}+\mathrm{m}_{3} \mathrm{~h}_{3}=\mathrm{m}_{4} \mathrm{~h}_{4}+\mathrm{m}_{2} \mathrm{~h}_{2}
\end{gathered}
$$

Coefficient of performance

$$
\mathrm{COP}=\frac{\mathrm{Q}_{\mathrm{EV}}}{\mathrm{Q}_{\mathrm{GE}}}
$$

\section{Appendix A.3. Validation}

The COP obtained from the CAS simulation were compared with simulations reported by different authors for each working mixture.

\section{Appendix A.3.1. $\mathrm{H}_{2} \mathrm{O}-\mathrm{LiBr}$ System}

The $\mathrm{H}_{2} \mathrm{O}-\mathrm{LiBr}$ thermodynamic properties were obtained from the publication of Patek and Klomfar [20] programed as a library routine in the EES software. The COP obtained in this study was compared with that of the Gogoi and Konwar [13] simulation at different temperatures conditions as shown in Table A1. The COP difference percent was lower than $2.6 \%$ between the present simulation and the bibliography.

Table A1. Simulation results of the $\mathrm{H}_{2} \mathrm{O}-\mathrm{LiBr}$ absorption cooling system.

\begin{tabular}{ccccccc}
\hline $\mathbf{T}_{\mathbf{E V}},{ }^{\circ} \mathbf{C}$ & $\mathbf{T}_{\mathbf{G E}},{ }^{\circ} \mathbf{C}$ & $\mathbf{T}_{\mathbf{C O}},{ }^{\circ} \mathbf{C}$ & $\mathbf{T}_{\mathbf{A B}},{ }^{\circ} \mathbf{C}$ & $\mathbf{C O P}[13]$ & COP, Author & Difference, $\%$ \\
\hline 4 & 70 & 31 & 31 & 0.79 & 0.79 & 0.9 \\
5 & 66 & 28 & 35 & 0.77 & 0.76 & 0.8 \\
6 & 72 & 33 & 37 & 0.73 & 0.73 & 0.5 \\
8 & 85 & 46 & 39 & 0.58 & 0.60 & -2.6 \\
9 & 66 & 28 & 34 & 0.84 & 0.83 & 0.7 \\
\hline
\end{tabular}

\section{Appendix A.3.2. $\mathrm{H}_{2} \mathrm{O}-\mathrm{LiCl}$ System}

The $\mathrm{H}_{2} \mathrm{O}-\mathrm{LiCl}$ thermodynamic properties were obtained from the publication of Patek and Klomfar [21] (heat capacity) and Conde [22] (concentration, density, and enthalpy). The COP obtained in this study was compared with that of the Gogoi and Konwar [13] simulation at different temperatures conditions as shown in Table A2. The COP difference percent was lower than $10 \%$ between the present simulation and the bibliography.

Table A2. Simulation results of the $\mathrm{H}_{2} \mathrm{O}-\mathrm{LiCl}$ absorption cooling system.

\begin{tabular}{ccccccc}
\hline $\mathbf{T}_{\mathbf{E V}},{ }^{\circ} \mathbf{C}$ & $\mathbf{T}_{\mathrm{GE}},{ }^{\circ} \mathbf{C}$ & $\mathbf{T}_{\mathbf{C O}},{ }^{\circ} \mathbf{C}$ & $\mathbf{T}_{\mathbf{A B}},{ }^{\circ} \mathbf{C}$ & $\mathbf{C O P}[13]$ & COP, Author & Difference \% \\
\hline 4 & 70 & 31 & 31 & 0.86 & 0.82 & 3.6 \\
5 & 66 & 28 & 35 & 0.86 & 0.82 & 4.8 \\
6 & 72 & 33 & 37 & 0.84 & 0.79 & 5.7 \\
8 & 85 & 46 & 39 & 0.81 & 0.73 & 10.0 \\
9 & 66 & 28 & 34 & 0.85 & 0.86 & 2.7 \\
\hline
\end{tabular}

\section{Appendix A.3.3. $\mathrm{NH}_{3}-\mathrm{LiNO}_{3}$ System}

$\mathrm{The} \mathrm{NH}_{3}-\mathrm{LiNO}_{3}$ thermodynamic properties were obtained from the publication of Infante Ferreira [23]. Table A3 shows the values of COP obtained from the Sun simulation [12] and from the present work at an evaporator temperature $=-5{ }^{\circ} \mathrm{C}$ and condenser and absorber $=25{ }^{\circ} \mathrm{C}$. The COP difference percent is lower than $8 \%$. 
Table A3. Simulation results of the $\mathrm{NH}_{3}-\mathrm{LiNO}_{3}$ absorption cooling system.

\begin{tabular}{cccc}
\hline $\mathrm{T}_{\mathrm{GE}}{ }^{\circ} \mathrm{C}$ & COP [12] & COP, Author & Difference \% \\
\hline 60 & 0.52 & 0.54 & 3.4 \\
65 & 0.60 & 0.65 & 7.7 \\
75 & 0.64 & 0.67 & 5.5 \\
85 & 0.64 & 0.67 & 4.5 \\
95 & 0.64 & 0.65 & 2.6 \\
\hline
\end{tabular}

\section{Appendix A.3.4. $\mathrm{NH}_{3}-\mathrm{NaSCN}$ System}

The $\mathrm{NH}_{3}-\mathrm{NaSCN}$ thermodynamic properties were obtained from the publication of Ferreira [23]. Table A4 shows the values of COP obtained from the Sun simulation [12] and the present work at an evaporator temperature $=-5^{\circ} \mathrm{C}$ and condenser and absorber $=25^{\circ} \mathrm{C}$. The COP difference percent is lower than $8 \%$.

Table A4. Simulation results of the $\mathrm{NH}_{3}-\mathrm{NaSCN}$ absorption cooling system.

\begin{tabular}{cccc}
\hline $\mathbf{T}_{\mathrm{GE}},{ }^{\circ} \mathbf{C}$ & COP [12] & COP, Author & Difference $\%$ \\
\hline 65 & 0.53 & 0.55 & 3.99 \\
75 & 0.62 & 0.65 & 4.29 \\
85 & 0.63 & 0.66 & 4.70 \\
95 & 0.63 & 0.66 & 3.21 \\
\hline
\end{tabular}

\section{Appendix A.3.5. $\mathrm{NH}_{3}-\mathrm{H}_{2} \mathrm{O}$ System}

The $\mathrm{NH}_{3}-\mathrm{H}_{2} \mathrm{O}$ thermodynamic properties were obtained from the publication of Ibrahim and Klein [24] programmed as an EES Library routine in the EES software. Table A5 shows the values of COP obtained from the Sun simulation [12] and the present work at an evaporator temperature $=-5^{\circ} \mathrm{C}$ and condenser and absorber $=$ $25^{\circ} \mathrm{C}$. The COP difference percent is lower than $13 \%$.

Table A5. Simulation results of the $\mathrm{NH}_{3}-\mathrm{H}_{2} \mathrm{O}$ absorption cooling system.

\begin{tabular}{cccc}
\hline $\mathrm{T}_{\mathrm{GE}}{ }^{\circ} \mathrm{C}$ & COP [12] & COP, Author & Difference $\%$ \\
\hline 65 & 0.54 & 0.56 & 3.90 \\
75 & 0.62 & 0.63 & 1.21 \\
85 & 0.62 & 0.62 & 0.26 \\
100 & 0.62 & 0.60 & 4.67 \\
120 & 0.62 & 0.54 & 12.75 \\
\hline
\end{tabular}

\section{References}

1. Gilania, S.I.; Ahmed, M.S. Solution crystallization detection for double-effect $\mathrm{LiBr}-\mathrm{H}_{2} \mathrm{O}$ steam absorption chiller. Energy Procedia 2015, 75, 1522-1528. [CrossRef]

2. Ahmed, M.S.; Waheed, A.; Talha, T.; Wajahat, M.; Sarfraz, F. Configuration based modeling and performance analysis of single effect solar absorption cooling system in TRNSYS. Energy Convers. Manag. 2018, 157, 351-363.

3. Stanciu, C.; Stanciu, D.; Gheorghian, A.T. Thermal analysis of a solar powered absorption cooling system with fully mixed thermal storage at startup. Energies 2017, 10, 72. [CrossRef]

4. Stanciu, C.; Stanciu, D.; Gheorghian, A.-T.; Tănase, E.-B.; Dobre, C.; Spiroiu, M. Maximum exergetic efficiency operation of a solar powered $\mathrm{H}_{2} \mathrm{O}-\mathrm{LiBr}$ absorption cooling system. Entropy 2017, 19, 676. [CrossRef]

5. Sokhansefat, T.; Mohammadi, D.; Kasaeian, A.; Mahmoudi, A.R. Simulation and parametric study of a 5-ton solar absorption cooling system in Tehran. Energy Convers. Manag. 2017, 148, 339-351. [CrossRef]

6. Antonopoulos, K.A.; Rogdakis, E.D. Performance of solar-driven ammonia-lithium nitrate and ammonia-sodium thiocyanate absorption systems operating as coolers or heat pumps in Athens. Appl. Therm. Eng. 1996, 16, 127-147. [CrossRef]

7. Florides, G.A.; Kalogirou, S.A.; Tassou, S.A.; Wrobel, L.C. Modelling and simulation of an absorption solar cooling system for Cyprus. Sol. Energy 2002, 72, 43-51. [CrossRef] 
8. Arzoz, D.; Venegas, M.; Izquierdo, M.; Rodríguez, P. Solar absorption refrigeration cycle using $\mathrm{LiNO}_{3}-\mathrm{NH}_{3}$ solution and flat plate collectors. In Proceedings of the International Sorption Heat Pump Conference, Shangai, China, 24-27 September 2002.

9. De Francisco, A.; Illanes, R.; Tones, J.L.; Castillo, M.; De Bias, M.; Prieto, E.; García, A. Development and testing of a prototype of low power water-ammonia absorption equipment for solar energy applications. Renew. Energy 2002, 25, 537-544.

10. Asim, M.; Dewsbury, J.; Kanana, S. TRNSYS simulation of a solar cooling system for the hot climate of Pakistan. Energy Procedia 2016, 91, 702-706. [CrossRef]

11. Agrouaza, Y.; Bouhal, T.; Allouhi, A.; Kousksou, T.; Jamil, A.; Zeraouli, Y. Energy and parametric analysis of solar absorption cooling systems in various Moroccan climates. Case Stud. Therm. Eng. 2017, 9, $28-39$. [CrossRef]

12. Sun, D.W. Comparison of the performances of $\mathrm{NH}_{3}-\mathrm{H}_{2} \mathrm{O}, \mathrm{NH}_{3}-\mathrm{LiNO}_{3}$ and $\mathrm{NH}_{3}-\mathrm{NaSCN}$ absorption refrigeration systems. Energy Convers. Manag. 1998, 39, 357-368. [CrossRef]

13. Gogoi, T.K.; Konwar, D. Exergy analysis of a $\mathrm{H}_{2} \mathrm{O}-\mathrm{LiCl}$ absorption refrigeration system with operating temperatures estimated through inverse analysis. Energy Convers. Manag. 2016, 110, 436-447. [CrossRef]

14. Solar Energy Laboratory. TRNSYS 18, a Transient System Simulation Program. Available online: http: / / sel.me.wisc.edu/trnsys (accessed on 21 January 2018).

15. Klein SA. EES, Engineering Equation Solver; Professional Version; FChart Software: Madison, WI, USA, 2017; Available online: http:/ / www.fchart.com/ees/ (accessed on 21 January 2018).

16. Solar Rating \& Certification Corporation. Directory of SRCC Certified Solar Collector Ratings; Solar Rating \& Certification Corporation: Washington, DC, USA, 2009.

17. Solar Energy Laboratory. TRNSYS 17 mathematical reference. In Available under the TRNSYS 17 Help Menu; Solar Energy Laboratory: Madison, WI, USA, 2017.

18. Klein, S.A. EES Engineering Equation Solver, User Manual, F-Chart Software. Available online: http: / / www.unh.edu/p2/ihf/ees.pdf (accessed on 1 November 2018).

19. Cerezo, J. Study of Absorption Process with Ammonia-Water Using Plate Heat Exchanger for Absorption Refrigeration Machines. Ph.D. Thesis, Universitat Rovira i Virgili, Tarragona, Cataluña, Spain, 2006. (In Spanish)

20. Patek, J.; Klomfar, J. A computationally effective formulation of the thermodynamic properties of $\mathrm{LiBr}-\mathrm{H}_{2} \mathrm{O}$ from 273 to $500 \mathrm{~K}$ over full composition range. Int. J. Refrig. 2006, 29, 566-578. [CrossRef]

21. Patek, J.; Klomfar, J. Thermodynamic properties of the $\mathrm{LiCl}-\mathrm{H}_{2} \mathrm{O}$ system at vapor-liquid equilibrium from $273 \mathrm{~K}$ to $400 \mathrm{~K}$. Int. J. Refrig. 2008, 31, 287-303. [CrossRef]

22. Conde, M. Aqueous Solution of Lithium and Calcium Chlorides: Property Formulations for Use in Air Conditioning Equipment Design. 2014. Available online: www.mrc-eng.com/Downloads/Aqueous\% 20LiCl\&CaCl2\%20Solution\%20Props.pdf (accessed on 20 January 2018).

23. Infante-Ferreira, C.A. Thermodynamic and physical property data equations for ammonia-lithium nitrate and ammonia-sodium thiocyanate solutions. Sol. Energy 1984, 32, 231-236. [CrossRef]

24. Ibrahim, O.M.; Klein, S.A. Thermodynamic Properties of Ammonia-Water Mixtures, ASHRAE. Transactions 1993, 99, 1495-1502.

(C) 2018 by the authors. Licensee MDPI, Basel, Switzerland. This article is an open access article distributed under the terms and conditions of the Creative Commons Attribution (CC BY) license (http:/ / creativecommons.org/licenses/by/4.0/). 